\title{
Prospective study for validation of a single protocol for the 13C-urea breath test using two different devices in the diagnosis of $\boldsymbol{H}$. pylori infection
}

\author{
Luiz Gonzaga Vaz COELHO, Osmar Reni TRINDADE, Laiane Alves LEÃO, Henrique Gomes RIBEIR0, \\ Izabella Silva FREITAS and Maria Clara Freitas COELHO
}

Received 8/4/2019

\begin{abstract}
Background $-{ }^{13} \mathrm{C}$-urea breath test (UBT) is the gold-standard, noninvasive method for $H$. pylori diagnosis. However, there is no uniform standardization of the test. This situation can be unpractical for laboratories running with two or more devices. Objective - To perform a prospective comparison validation study of UBT employing one validated protocol for two different devices: BreathID Hp Lab System ${ }^{\circledR}$ (Exalenz Bioscience Ltd, Israel), here called device A and IRIS-Doc $2^{\circledR}$ (Wagner Analysen-Technik, Germany, now Mayoly Spindler Group, France), here called device B, in the diagnosis of $H$. pylori infection. Methods - A total of 518 consecutive patients ( 365 females, 153 males, mean age 53 years) referred for UBT were included. All patients received device A protocol as follow: after at least one hour fasting, patients filled two bags prior to the test, then ingested an aqueous solution containing $75 \mathrm{mg}$ of ${ }^{13} \mathrm{C}$-urea with a $4.0 \mathrm{~g}$ citric acid powder and filled another two bags $15 \mathrm{~min}$ after ingesting the test solution. One pair of breath sample bags (before and after ingestion) was analyzed by the two different devices. A delta over baseline (DOB) $\geq 5 \%$ indicated $H$. pylori infection. Statistics: Wilcoxon test, kappa coefficient with 95\% CI, Wilson's method. Results - Considering the device A protocol as the gold standard, its comparison with device B showed a sensitivity of 99.3\% (95\% CI: 96.3-99.9) and a specificity of 98.9\% (95\% CI: 97.3-99.6). Kappa coefficient was 0.976 (95\% IC: 0.956-0.997). Conclusion - Correlation between the two devices was excellent and supports a uniform standardization of UBT. HEADINGS - Helicobacter infections, diagnosis. Breath tests. Urea, analysis. Carbon isotopes, analysis.
\end{abstract}

\section{INTRODUCTION}

Helicobacter pylori is recognized as the main etiologic agent of peptic ulcers, with a pathogenic role equally well established in gastric adenocarcinoma and MALT (mucosa-associated lymphoid tissue) lymphoma ${ }^{(1,2)}$. First identified in 1983 by Marshall and Warren $^{(3)}$ from gastric tissue fragments, since then, different diagnostic methods have been developed for their detection, including invasive and non-invasive tests. Invasively, the bacterial presence can be identified through gastroscopy by the collection of gastric fragments for histology, culture, urease test or molecular tests. Non-invasive tests consist of serological tests, stool antigen detection, and the ${ }^{13} \mathrm{C}$ urea breath test $(\mathrm{UBT}){ }^{(4)}$.

UBT is the gold-standard noninvasive method for $H$. pylori diagnosis, with a sensitivity and specificity greater than $95 \%{ }^{(5-7)}$. Due to its high accuracy, low cost and easy performance, it is considered the first option in the control of $H$. pylori infection treatment or recurrence and it is a fundamental diagnostic tool in the "test and treat" strategy; it is also an excellent option in epidemiological studies ${ }^{(8-10)}$. Such tests are based on the property of $H$. pylori in producing high amounts of urease enzyme. The principle of the test is based on the ability of $H$. pylori (if present in the gastric environment) to break down orally absorbed
${ }^{13} \mathrm{C}$-labelled urea. ${ }^{13} \mathrm{CO}_{2}$ diffuses into the blood and is excreted via the lungs and can be easily measured in the expired air using mass or non-dispersive, isotope-selective infrared spectroscopy ${ }^{(11)}$. Thus, the analysis of samples of expired air collected before (control) and after substrate ingestion will indicate the change in the ${ }^{13} \mathrm{CO}_{2}{ }^{12} \mathrm{CO}_{2}$ ratio caused by the metabolic activity induced by the administration of the labelled urea.

Since its original description in 1987 by Graham et al. ${ }^{(12)}$, UBT has undergone several modifications involving the need or not of fasting before the test ${ }^{(13)}$, dose of ${ }^{13} \mathrm{C}$-urea employed ${ }^{(11)}$, concomitant administration of ${ }^{13} \mathrm{C}$-urea in any citrus meal ${ }^{(14)}$, ideal sample collection time for exhaled air after substrate ingestion, optimal cut-off point and performance of the device used to perform $\mathrm{UBT}^{(13,15)}$. Thus, there is no single worldwide standardization for testing to date, although numerous individual validation studies confirm the high accuracy of the method for the diagnosis of active $H$. pylori in adults and children over 6 years of age ${ }^{(4-10,16-18)}$.

Considering the current moment, where there are several devices in the world market, including hospitals and clinics working with more than one device from different manufacturers in the daily routine, the search for a single UBT preparation and reading protocol should be investigated to standardize processes and improve efficiency. 
The aim of this study is to perform a prospective comparison validation study of ${ }^{13} \mathrm{C}$-urea breath test for the diagnosis of $H$. pylori infection employing one validated protocol for two different devices.

\section{METHODS}

The study was performed at the Breath Tests Laboratory of the Alfa Institute of Gastroenterology at Clinics Hospital of Federal University of Minas Gerais, Belo Horizonte, MG, Brazil.

\section{Patients}

We recruited individuals consecutively referred for UBT for the purpose of the initial diagnosis or control of $H$. pylori infection treatment from November 2017 to September 2018. Informed consent was obtained from all patients to participate in the study after being duly informed about the purpose of the study. The study inclusion criterion was the non-use of proton pump inhibitors or antibiotics in the last 14 or 30 days, respectively, prior to UBT.

\section{${ }^{13}$ C-urea Breath Test (UBT)}

All study participants underwent UBT, which was processed and analysed simultaneously by two different devices. Our laboratory has two devices: the BreathID HP Lab System ${ }^{\circledR}$ (Exalenz Bioscience Ltd, Israel), here called device A, and IRIS-Doc $2^{\circledR}$ (Wagner Analysen-Technik, Bremen, Germany, now Mayoly Spindler Group, France), here called device B. Although these two devices have independent protocols previously validated and recommended by the manufacturers ${ }^{(17,19)}$, we chose a single protocol as recommended by the manufacturer of device A, cleared by FDA in November 2016, due its particularities and practicity ${ }^{(19)}$.

The protocol employed can be summarized as follows: after at least $1 \mathrm{~h}$ fasting, exhaled air samples were initially collected from the participants in two small collection bags $(120 \mathrm{~mL})$, which corresponded to time zero (sample-1, control). Next, the patients ingested, within $2 \mathrm{~min}$, an aqueous solution $(200 \mathrm{~mL})$ containing $75 \mathrm{mg}$ of ${ }^{13} \mathrm{C}$-urea and $4.0 \mathrm{~g}$ of citric acid powder, with added edulcorant. A second exhaled air collection was performed $15 \mathrm{~min}$ after the ingestion of the substrate in two new small collection bags, which corresponded to sample-2. Each pair of collected material (sample-1 and sample-2) was analysed and processed by one of the two infrared analyser devices of the study. According to the manufacturer's instructions, patients were considered positive for H. pylori when they had a delta over baseline (DOB) equal to or greater than $5 \% 0^{(19)}$. This parameter indicates the change in the ${ }^{13} \mathrm{CO}_{2} /{ }^{12} \mathrm{CO}_{2}$ ratio in metabolic activity induced by the administration of the labelled urea.

For statistical analysis, the data were expressed as percentages, means (standard deviation), median and minimum and maximum values. Continuous variables were compared using t-test or the
Mann-Whitney test (non-parametric data) and Wilcoxon test for paired samples. The coefficient of concordance (kappa) of the tests between the two devices was calculated. Considering device A, whose protocol was used in the study as the gold standard, the sensitivity, specificity and $95 \%$ confidence interval were calculated for the results obtained with device B. Wilson's method was used to calculate the confidence intervals ${ }^{(20)}$. All statistical analyses were performed using the MINITAB statistical package (Minitab Inc., State College, PA, USA) version 16 and Excel (Office 10).

\section{RESULTS}

Five hundred eighteen patients were consecutively included in the study: $365(70.5 \%)$ patients were women and 153 were men $(29.5 \%)$, with a mean age of 53 years (10-89 years) and a standard deviation (SD) of 15.3 years. Among the 518 patients, 161 had never received anti- $H$. pylor $i$ treatment and 357 patients underwent the test to evaluate the anti- $H$. pylori treatment result.

TABLE 1 shows the observed values in DOB\%o in the UBT obtained using the single protocol (device A) in the two different devices.

FIGURE 1 shows the absolute values of $\mathrm{DOB} \%$ observed in all 518 study participants. Considering the cut-off point of DOB $\geq 5 \%$ for the presence of $H$. pylori, only $5 / 518$ participants (FIGURE 2) presented discordant results between the two devices, a positive participant on device $\mathrm{A}$ and a negative one on device $\mathrm{B}$, while four subjects were negative on device A and positive on device B. Four in five participants with discordant results underwent the test for post-

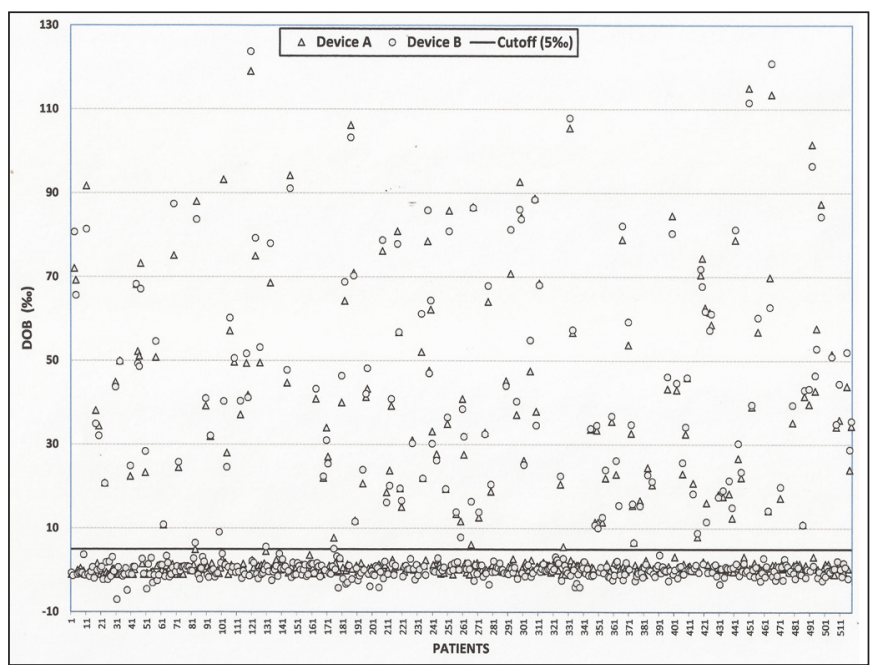

FIGURE 1. Absolute values of DOB\%o observed in device A and device B for all 518 study participants. DOB: delta over baseline.

TABLE 1. UBT results employing two different devices with a unique protocol $(\mathrm{n}=518)$.

\begin{tabular}{|c|c|c|c|c|c|c|}
\hline \multirow{2}{*}{ DOB \%o } & \multicolumn{3}{|c|}{ Device A } & \multicolumn{3}{|c|}{ Device B } \\
\hline & All & Negative & Positive & All & Negative & Positive \\
\hline Mean value (SD) & $13.1(24.7)$ & $0.4(1.0)$ & $44.8(26.9)$ & $12.9(24.9)$ & $-0.1(1.5)$ & $44.6(26.7)$ \\
\hline Min. value & -1.0 & -1.0 & 5.6 & -7.0 & -7.0 & 5.1 \\
\hline Max. value & 119.1 & 4.9 & 119.1 & 123.8 & 3.9 & 123.8 \\
\hline
\end{tabular}

UBT: ${ }^{13} \mathrm{C}$-urea breath test; DOB: delta over baseline; SD: standard deviation. 


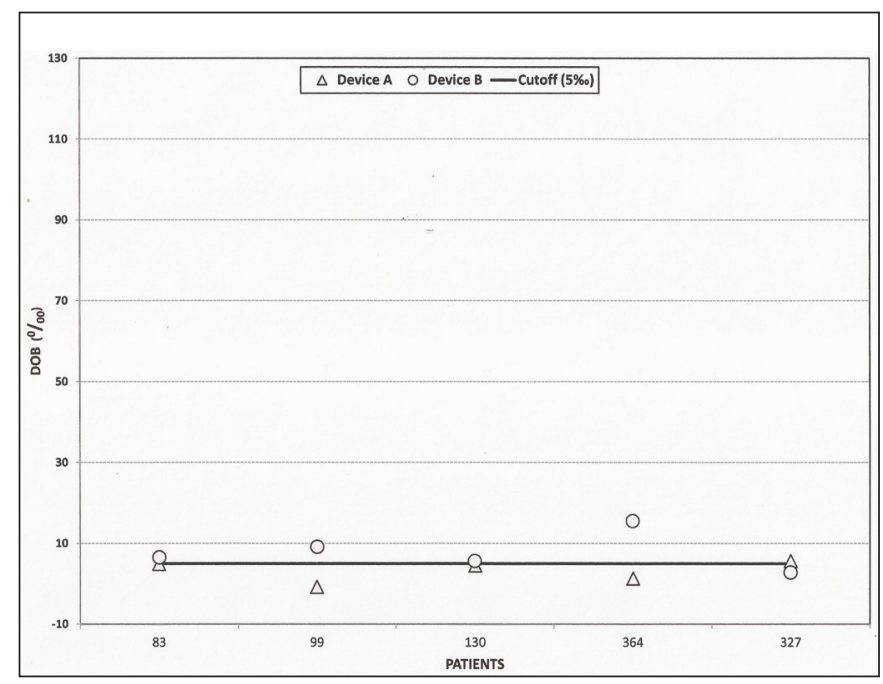

FIGURE 2. Discordant absolute values of DOB \%o between device $A$ and device B in 518 cases. DOB: delta over baseline.

treatment infection control. The kappa coefficient of concordance between the two devices was 0.976 (95\% CI: 0.956-0.997). Considering the device A protocol as the gold standard, its comparison with device B showed a sensitivity of 99.3\% (95\% CI: 96.3-99.9) and a specificity of $98.9 \%$ (95\% CI: 97.3-99.6).

TABLE 2 shows the absolute values of DOB $\%$ observed in patients with confirmed $H$. pylori in both devices $(n=147)$; significantly higher values are observed in both devices for the female population compared with the male population.

TABLE 2. DOB\%o absolute values in $H$. pylori-infected patients ( $\mathrm{n}=147)$, regarding sex.

\begin{tabular}{lcccc}
\hline \multirow{2}{*}{ Variables } & \multicolumn{2}{c}{ Device A } & \multicolumn{2}{c}{ Device B } \\
\cline { 2 - 5 } & Male & Female & Male & Female \\
\hline Mean (SD) & $36.4(21.9)$ & $47.5(27.8)^{*}$ & $35.8(21.2)$ & $47.4(27.8)^{* *}$ \\
Median & 33.5 & 41.4 & 30.3 & 43.1 \\
Min & 6.1 & 5.6 & 5.6 & 5.1 \\
Max & 87.4 & 119.1 & 84.4 & 123.8 \\
\hline
\end{tabular}

DOB\%o: delta over baseline; $* P=0.036 ; * * P=0.027$.

\section{DISCUSSION}

Our study shows that the UBT employing the same protocol for two different devices from two different manufacturers presented very similar results. This allows their standardization in daily practice. Only $5 / 518(0.97 \%)$ participants (four of them performed for treatment control) showed discordant results, and the DOB values were close to the cut-off point in three of them. Characteristically, in the UBT, DOB\%o values in individuals infected or not infected by $H$. pylori are situated far from the established cut-off point, and our study shows very similar absolute values, both positive and negative, between the two devices analysed. Typically, borderline cut-off UBT observed values (grey or indeterminate zone) should be interpreted with caution, and it is suggested that the test should be repeated or the diagnosis should be confirmed by another method. The prevalence of UBT results in the grey area has been estimated at $1 \%$ to $2 \%$, similar to the one observed here ${ }^{(21,22)}$.
In its initial description, UBT was performed using isotope ratio mass spectrometry technology, which has a high cost and complexity regarding use and maintenance ${ }^{(12)}$. More recently, UBT has been performed using non-dispersive, isotope-selective infrared spectroscopes, which has a lower cost, smaller size, easy maintenance and operation, and which results are available a few minutes after the procedure; this allows UBT to be carried out in doctors' offices or small-to-medium sized laboratories. Its excellent performance has made this methodology attractive to the industry and physicians, since there are numerous devices being commercialized in the international market ${ }^{(11,23,24)}$. Despite the existence of small variations in the methods employed by each device, regarding fasting time before UBT, ideal test meal, best ${ }^{13} \mathrm{C}$-urea dose, optimal breath sampling after ingestion of the substrate and best cut-off point to discriminate infected from non-infected individuals, several local validation studies have shown high diagnostic accuracy to detect $H$. pylori infection ${ }^{(6,8)}$. However, the absence of definitive standardization of the test makes it impractical to manage different devices at the same place and to compare the results from different studies.

In our study, although the protocols for the two devices were previously validated, we chose to use the protocol suggested by device A for its practicity, especially in relation to fasting time ( $1 \mathrm{~h}$ instead of $8 \mathrm{~h}$ ), use of citric acid instead of orange juice and $15 \mathrm{~min}$ instead of $30 \mathrm{~min}$ for the optimal breath sampling after ingestion of the substrate. The fasting time of only one hour makes it more convenient to perform the test at different times, with several studies demonstrating that the differences between $\mathrm{DOB} \%$ values fasting or not fasting are minimal or non-existent $^{(25-28)}$. The incorporation of citric acid as a test meal instead of orange juice administered together with ${ }^{13} \mathrm{C}$-urea is currently well established ${ }^{(14,29)}$. Its administration delays gastric emptying, allowing the labelled substrate to distribute throughout the stomach and maximizes the reaction with the preformed bacterial urease. Additionally, it increases the hydrolysis of urea, both by increasing the availability of intracytoplasmic urea and increasing the activity of intragastric urease, providing higher ${ }^{13} \mathrm{CO}_{2}$ recovery values $^{(14,29)}$. Its effect is dose dependent, and the $4.0 \mathrm{~g}$ dose used here seems to be palatable and efficient to maximally enhance urease activity ${ }^{(29,30)}$. Recently, a new test meal using a high-dose mixture of citric, malic and tartaric acid has been proposed to be used as a test meal in patients taking proton pump inhibitors with good accuracy, although $7.2 \%$ of the patients complained of dyspeptic symptoms with the test meal ${ }^{(31)}$. The dose of ${ }^{13} \mathrm{C}$ urea administered is between $50 \mathrm{mg}$ and $100 \mathrm{mg}$, and $75 \mathrm{mg}$ is the dose most commonly used currently ${ }^{(11)}$. Studies have shown that doses above $125 \mathrm{mg}$ are unnecessary ${ }^{(32)}$, and a dose of $25 \mathrm{mg}$ is inefficient to provide good accuracy ${ }^{(33)}$. The interval of $15 \mathrm{~min}$ instead of $30 \mathrm{~min}$ as optimal breath sampling after ingestion of the substrate has been considered sufficient to avoid interference of the pharyngeal flora with the possible presence of ureaseproducing bacteria and sufficient to allow hydrolysis ${ }^{13} \mathrm{C}$-urea by contact with the preformed urease by $H$. pylori. The use of citric acid, might also contribute to obtain greater accuracy of UBT with the collection performed 15 min after substrate ingestion by increasing the saliva production and reducing possible interaction with the urease that might be present in the oral cavity ${ }^{(11,27,34)}$.

Our study also demonstrated that mean UBT values, in both devices, were significantly higher in females (device A: 47.5\%, SD:27.8, $P=0.036$ and device B:47.4\%, SD:27.8, $P=0.027)$ than 
in males (device A:36.4\%, SD:1.9, and device B:35.8\%, SD:21.2). These results demonstrate that, for the first time, using two distinct devices simultaneously corroborate findings already described in studies using only one device. This demonstrates that UBT has absolute values significantly higher in adult females than in adult males, with a significant increase varying from $4.5 \%$ to $11 \%$ in the median UBT, and similar to our results from $11.1 \%$ in device $\mathrm{A}$ and $11.6 \%$ in device $\mathrm{B}^{(35-39)}$. The reasons for these findings are still largely unknown. Variables such as higher bacterial density in women, hormonal changes, body surface area and sex differences in intragastric $\mathrm{pH}$ are being investigated, but further investigations are clearly needed ${ }^{(38,39)}$.

In conclusion, our study showed that UBT performed by two different devices employing a single protocol presents excellent agreement between them. This harmonization, while improving and simplifying the operational procedures, represents an important contribution in the search for a single standardization for UBT.

\section{Orcid}

Luiz Gonzaga Vaz Coelho. Orcid: 0000-0002-8721-7696.

Osmar Reni Trindade. Orcid: 0000-0003-1686-7365.

Laiane Alves Leão. Orcid: 0000-0001-6547-3798.

Henrique Gomes Ribeiro. Orcid: 0000-0001-8187-6378.

Izabella Silva Freitas. Orcid: 0000-0002-5500-8881.

Maria Clara Freitas Coelho. Orcid: 0000-0001-8028-6114.

\section{ACKNOWLEDGEMENTS}

The authors thank to Maurílio M. Fernandes and Maria de Lourdes M. Fernandes for technical and statistical assistance.

\section{Authors' contribution}

Coelho LG and Trindade OR contributed to the conception and design of the study; Leão LA and Trindade OR contributed to collection of the samples; Ribeiro HG and Freitas IS interpreted and analysed the data and Coelho LG and Coelho MC wrote the paper.

Coelho LGV, Trindade OR, Leão LA, Ribeiro HG, Freitas IS, Coelho MCF. Estudo prospectivo para validação de protocolo único para o teste respiratório com ureia marcada com carbono-13 empregando dois dispositivos diferentes, no diagnóstico da infecção por H. pylori. Arq Gastroenterol. 2019;56(2):197-201.

RESUMO - Contexto - O teste respiratório com ureia-marcada com carbono-13 (TR-13C) é o método padrão-ouro para o diagnóstico não invasivo da infecção por H. pylori. Apesar disto, não existe uma uniformização de protocolos para a sua realização, trazendo dificuldades operacionais para laboratórios ou clínicas que operam com equipamentos de fabricantes diferentes. Objetivo - Estudo prospectivo e comparativo para validação do TR-13C para o diagnóstico de infecção por H. pylori, com emprego de protocolo único para dois equipamentos diferentes, a saber: BreathID Hp Lab System $^{\circledR}$ (Exalenz Bioscience Ltd, Israel), aqui denominado equipamento A e IRIS-Doc2 ${ }^{\circledR}$ (Wagner Analysen-Technik, Alemanha, agora Mayoly Spindler Group, França), aqui denominado equipamento B. Métodos - Um total de 518 pacientes (365 mulheres e 153 homens, idade média de 53 anos) consecutivamente encaminhados para a realização do TR-13C foram incluídos no estudo. Todos os participantes realizaram TR-13C, que foi processado e analisado simultaneamente pelos dois equipamentos. Embora os dois equipamentos possuam protocolos independentes previamente validados, foi optado, por sua maior praticidade, pela utilização de um único protocolo, conforme recomendado pelo fabricante do equipamento A, e assim resumido: após jejum mínimo de $1 \mathrm{~h}$, foram amostras de ar expirado coletadas em dois pequenos sacos coletores $(120 \mathrm{~mL})$, correspondendo ao tempo-zero (amostra-1, controle). Em seguida, os pacientes ingeriram, em até $2 \mathrm{~min}$, uma solução aquosa (200 mL) contendo $75 \mathrm{mg}$ de $13 \mathrm{C}$-ureia e 4,0 gramas de ácido cítrico em pó, adicionado com edulcorante. Uma segunda coleta de ar expirado era realizada 15 min após a ingestão do substrato em dois novos pequenos sacos coletores, correspondendo à amostra-2. Foram considerados positivos para a presença da infecção por $H$. pylori quando apresentavam um delta over baseline (DOB) igual ou maior que 5\%. Análise estatística foi realizada com o teste de Wilcoxon, coeficiente kappa com IC $95 \%$ e método de Wilson. Resultados - Considerando o protocolo do equipamento A como o padrão-ouro, sua comparação com o equipamento B mostrou sensibilidade de 99,3\% (IC 95\%: 96,3-99,9) e especificidade de 98,9\% (IC 95\%: 97,3-99,6). O coeficiente kappa observado foi de 0,976 (IC 95\%: 0,956-0,997). Conclusão-A correlação entre os dois equipamentos foi excelente e contribui para uma uniformização de protocolos para TR-13C DESCRITORES - Infecções por Helicobacter, diagnóstico. Testes respiratórios. Ureia, análise. Isótopos de carbono, análise.

\section{REFERENCES}

1. Suerbaum S, Michetti P. Helicobacter pylori infection. N Engl J Med. 2002; 10;347:1175-86

2. Fock KM, Graham DY, Malfertheiner P. Helicobacter pylori research: historical insights and future directions. Nat Rev Gastroenterol Hepatol. 2013;10 495-500.

3. Marshall BJ, Warren JR. Unidentified curved bacilli in the stomach of patients with gastritis and peptic-ulceration. Lancet. 1984;1:1311-5.

4. Megraud F, Lehours P. Helicobacter pylori detection and antimicrobial susceptibility testing. Clin Microbiol Rev. 2007;20:280-322.

5. Ling D. Carbon-13 urea breath test for Helicobacter pylori infection in patients with uninvestigated ulcer-like dyspepsia: an evidence-based analysis. Ont Health Technol Assessment Series [Internet]. 2013;13:1-30. Available from: https://www. hqontario.ca/Portals/0/Documents/evidence/reports/full-report-urea-breath-test131003-en.pdf. Accessed March 3, 2019.

6. Ferwana M, Abdulmajeed I, Alhajiahmed A, Madani W, Firwana B, Hasan R, et al. Accuracy of urea breath test in Helicobacter pylori infection: meta-analysis. World J Gastroenterol. 2015;21:1305-14
7. Best LMJ, Takwoingi Y, Siddique S, Selladurai A, Gandhi A, Low B, et al. Non-invasive diagnostic tests for Helicobacter pylori infection. Cochrane Database of Systematic Reviews 2018, Issue 3. Art. No.: CD012080. DOI: 0.1002/14651858. CD012080.pub2.

8. Graham DY, Klein PD. Accurate diagnosis of Helicobacter pylori. 13C-urea breath test. Gastroenterol Clin North Am. 2000;885-93.

9. Malfertheiner P, Megraud F, O’Morain CA, Gisbert JP, Kuipers EJ, Axon AT, et al. Management of Helicobacter pylori infection-the Maastricht V/Florence Consensus Report. Gut. 2017;66:6-30.

10. Coelho LGV, Marinho JR, Genta R, Ribeiro LT, Passos MDCF, Zaterka S, et al. 4th Brazilian Consensus Conference on Helicobacter pylori infection. Arq Gastroenterol. 2018;55:97-121.

11. Gisbert JP, Pajares JM. 13C-urea breath test in the diagnosis of Helicobacter pylori infection - a critical review. Aliment Pharmacol Ther. 2004;20:1001-7.

12. Graham DY, Klein PD, Evans DJ Jr, Evans DG, Alpert LC, Opekun AR, Boutton TW. Campylobacter pylori detected noninvasively by the $13 \mathrm{C}$-urea breath test. Lancet. 1987;1:1174-7. 
13. Mana F, Franken PR, Ham HR, Reynaert H, Urbain D. 13C urea breath test with nondispersive isotope-selective infrared spectrometry: reproducibility and importance of the fasting status. Helicobacter. 2000;5:104-8.

14. Dominguez-Mufioz JE, Leodolter A, Sauerbruch T, Malfertheiner P. A citric acid solution is an optimal test drink in the 13C-urea breath test for the diagnosis of Helicobacter pylori infection. Gut.1997;40:459-62

15. Parente F, Bianchi Porro G. The (13)C-urea breath test for non-invasive diagnosis of Helicobacter pylori infection: which procedure and which measuring equipment? Eur J Gastroenterol Hepatol. 2001;13:803-6.

16. Perri F. Diagnosis of Helicobacter pylori infection: which is the best test? The urea breath test. Dig Liver Dis. 2000;32 (Suppl 3):S196-8

17. Coelho LG, Reber M, Passos MC, et al. Application of isotope-selective non-dispersive infrared spectrometry for the evaluation of the 13C-urea breath test: comparison with three concordant methods. Braz J Med Biol Res. 1999;32: 1493-7.

18. Kawakami E, Machado RS, Reber M, Patrício FR. 13C-urea breath test with infrared spectroscopy for diagnosing Helicobacter pylori infection in children and adolescents. J Pediatr Gastroenterol Nutr. 2002;35:39-43.

19. Shirin H, Gonzalez JO, Hazan S, Gottlieb G, Friedenberg K, Gatof D, et al. The validity of breath collection bags using the novel BreathID ${ }^{\circ}$ Hp Lab System: a multicenter clinical study in 257 subjects. Ther Adv Gastrointest Endosc. 2019; 12:2631774519843401.

20. Altman DG, Bryant TN, Gardner MJ (eds). Statistics with confidence. Bristol: British Medical Journal; 2000.

21. Gisbert JP, Olivares D, Jiménez I, Pajares JM. Long-term follow-up of 13C-urea breath test results after Helicobacter pylori eradication: frequency and significance of borderline $\triangle 13 \mathrm{CO} 2$ values. Aliment Pharmacol Ther. 2006;23:275-80.

22. Chen TS, Chang FY, Chen PC, Huang TW, Ou JT, Tsai MH, et al. Simplified $13 \mathrm{C}$-urea breath test with a new infrared spectrometer for diagnosis of Helicobacter pylori infection. J Gastroenterol Hepatol. 2003;18:1237-43.

23. Opekun AR, Gotschall AB, Abdalla N, Agent C, Torres E, Sutton FM, et al. Improved infrared spectrophotometer for point-of-care patient $13 \mathrm{C}$-urea breath testing in the primary care setting. Clin Biochem. 2005;38:731-4.

24. Gisbert JP, Gomollon F, Dominguez-Munoz JE, et al. Comparison between two 13C-urea breath tests for the diagnosis of Helicobacter pylori infection: isotope ratio mass spectrometer versus infrared spectrometer. Gastroenterol Hepatol. 2003;26:141-6

25. Graham DY, Malaty HM, Cole RA, Martin RF, Klein PD. Simplified 13C-urea breath test for detection of Helicobacter pylori infection. Am J Gastroenterol. 2001;96:1741-5.
26. Ng FH, Lai KC, Wong BC, Wong WM, Wong SY, Chow KC, et al. [13C]-urea breath test without prior fasting and without test meal is accurate for the detection of Helicobacter pylori infection in Chinese. J Gastroenterol Hepatol. 2002;17:834-8.

27. Wang WM, Lee SC, Wu DC, Chen LT, Liu CS, Peng CF, et al. Simplified 13C-urea breath test for the diagnosis of Helicobacter pylori infection-The availability of without fasting and without test meal. Kaohsiung J Med Sci. 2000;16:607-13.

28. Moayyedi P, Braunholtz D, Heminbrough E, Clough M, Tompkins DS, Mapstone NP, et al. Do patients need to fast for a 13C-urea breath test? Eur J Gastroenterol Hepatol. 1997;9:275-7.

29. Graham DY, Miftahussurur M. Helicobacter pylori urease for diagnosis of Helicobacter pylori infection: A mini review. J Adv Res. 2018;13:51-7.

30. Graham DY, Runke D, Anderson SY, Malaty HM, Klein PD. Citric acid as the test meal for the 13C-urea breath test. Am J Gastroenterol. 1999;94:1214-7.

31. Tepes B, Malfertheiner P, Labenz J, Aygen S. Modified Helicobacter test using a new test meal and a $13 \mathrm{C}$-urea breath test in Helicobacter pylori positive and negative dyspepsia patients on proton pump inhibitors. Prospective Study. World J Gastroenterol. 2017;23:5954-61

32. Klein PD, Malaty HM, Martin RF, Graham KS, Genta RM, Graham DY. Noninvasive detection of Helicobacter pylori infection in clinical practice: the 13C urea breath test. Am J Gastroenterol. 1996;91:690-4.

33. Coelho LGV, Silva Jr AE, Coelho MCF, Penna FGC, Ferreira ROA, Santa-Cecilia EV. Does low dose 13C-urea breath test maintain a satisfactory accuracy in diagnosing Helicobacter pylori infection? Arq Gastroenterol. 2011;48:104-8

34. Eggers RH, Kukp A, Tegeler R, Ludtke FE, Lepsien G, Meyer B. A methodological analysis of the $13 \mathrm{C}$-urea breath tests for detection of Helicobacter pylori infections: high sensitivity and specificity within 30 minutes using $75 \mathrm{mg}$ of 13C-urea. Eur J Gastroenterol Hepatol. 1990;2:437-44.

35. Shmuely H, Yahav J, Samra Z, Chodick G, Ofek I. Elevated $13 \mathrm{C}$ urea breath test values females infected with Helicobacter pylori. Dig Dis Sci. 2007;52:402-4

36. Zevit N, Niv Y, Shirin H, Shamir R. Age and gender differences in urea breath test results. Eur J Clin Invest. 2011;41:767-72.

37. Marinho FP, Trindade OR, Ferreira KN, Amaral LA, Coelho LGV 13C-urea breath test values: a large database study focusing at gender differences. Helicobacter. 2012;17(Suppl. 1):92 [abstract]

38. Moshkowitz M, Horowitz N, Beit-Or A, Halpern Z, Santo E. Gender-associated differences in urea breath test for Helicobacter pylori infection referrals and results among dyspeptic patients. World J Gastrointest Pathophysiol. 2012;3:80-4.

39. Eisdorfer I, Shalev V, Goren S, Chodick G, Muhsen K. Sex differences in urea breath test results for the diagnosis of Helicobacter pylori infection: a large cross-sectional study. Biology of Sex Differences. 2018;9:1. 